\title{
NOVUM TESTAMENTUM A NOBIS VERSUM: 'THE ESSENCE OF ERASMUS' EDITION OF THE NEW TESTAMENT
}

Gohanni Trapman sacrum

ThE chapter which R. Pfeiffer devoted to Erasmus of Rotterdam in his History of Classical Scholarship from I 300 to 1850 , displays much evidence of knowledge of the subject and sound judgement. ${ }^{1}$ In this chapter Pfeiffer pays great attention to Erasmus' editions of the New Testament, the first of which appeared in 1516 . The reason for this is clear: 'Erasmus' Greek New Testament is his greatest humanistic work' and 'the correct starting point for assessing Erasmus' several services to learning must always be his edition of the Greek text of the New Testament, published in ${ }_{5}{ }_{1} 6$ in Basle'.

These two opinions contain a great deal of truth. That Erasmus was the first to make the Greek New Testament accessible to many in Western Europe by means of the printing press, remains a fact of evident importance. And it is clear that no verdict on Erasmus can be just which omits this achievement. Pfeiffer has an excellent grasp of the goal which Erasmus had in view in this edition. In the last analysis, Erasmus was not concerned with his technicalphilological achievement-even though he never considered himself too good for the mass of detailed work attached to the edition of texts. He wanted to open a direct path to the important early sources of knowledge. He wanted to supersede the circuitous route, via the corrupted tradition of a translation into dubious and easily misinterpreted Latin. Erasmus' edition, with its Greek text drawn from manuscripts, its new Latin translation and critical commentary, is par excellence the work of a philologist. But there was much more at stake for Erasmus: the purification of language and knowledge, the cultivation of manners and spirit and the improvement of man and society.

However correctly Pfeiffer saw all this, his verdict on Erasmus' edition of the New Testament is still capable of radical correction on a point of vital importance. The erroneous opinion to which I refer is in fact generally held; and I regard it as important, for the correct interpretation of Erasmus as editor and critic, to point out this misunderstanding and to attempt to set it right. I shall use this opportunity to correct a number of other traditional mistakes concerning Erasmus' New Testament.

1 Rudolf Pfeiffer, History of Classical Scholarship from 1300 to I 850 (Oxford, I976), ch. vii, 'Erasmus of Rotterdam', pp. 7 I-81. I cite from pp. 76 and 77.

[Journal of Theological Studies, N.S., Vol. 35, Pt. 2, October 1984] 
For a long time it has been customary, and in this such widely read authors as Pfeiffer, and Reynolds and Wilson join with numerous historians and Erasmus specialists, to speak of Erasmus' Novum Instrumentum (the title of the first impression of his edition of the New Testament) as, for example, 'his edition of the Greek Text of the New Testament'2 or 'the first publication of the Greek text of the New Testament' ${ }^{3}$ It 1 s of course true that the Novum Instrumentum was the first edition of the Greek New Testament ever published But were the Novum Instrumentum and the improved editions which Erasmus published in I 5 19, x 522, I 527, and $1535 \mathrm{in}$ intention and essence editions of the New Testament in Greek? In my opinion another comment by Pfeiffer is relevant here to himself also 'few modern scholars have taken the trouble to consider Erasmus' actual intentions ' ( $p$ 78)

The Novum Instrumentum, like the later issues printed in folio format, contains three main parts. the Greek text, Erasmus' own translation into Latın, and his Annotationes in Novum Testamentum The Greek and Latın texts are set out in parallel columns. on both right- and left-hand pages the Greek text forms the lefthand column and the Latin the right hand. The Annotationes are printed on separate pages. The Latin and Greek texts of the Gospels and Acts fill pages $1-322$, the texts of the Epistles and Revelation pages $323-4$ and a second series of pages numbered from I to 224. Immediately after this, the Annotationes fill pages $225^{-675}$. $^{4}$

For a variety of reasons I am of the opinion that Erasmus and his contemporaries regarded the Novum Instrumentum and its later editions in the first place as the presentation of the New Testament in a new Latın form, and not as an edition of the Greek text. I shall give a number of reasons for this view

The very title under which Erasmus published his work forms an immediate clue: Novum Instrumentum omne, diligenter ab Erasmo Roterodamo recognitum et emendatum, non solum ad Graecam veritatem, verumetiam ad multorum utriusque linguae codicum, postremo ad probatissimorum autorum citationem, emendationem et interpretationem, . . una cum Annotationibus, quae lectorem doceant, quid qua ratione mutatum sit The beginning of this title, Novum Instrumentum recognitum et emendatum, means 'The New

2 Ibid, p 76

${ }^{3}$ L D Reynolds and N G Wilson, Scribes and Scholars (Oxford, 1974²), p $\quad$ I 43

${ }_{4}$ The collational formula is as follows $3 a^{6} 3 b^{8} A-2 D^{6} a-h^{6} 1^{8} k-t^{6}(-t 6) \chi$ I $u-2 m^{6}$ $2 n^{8} 20-2 z^{6} 2 A-2 E^{6} 2 F^{8}$ I wish to thank Dr J A Gruys of The Hague for draw ing up this formula 
Testament ... revised and improved'. ${ }^{5}$ Since there was not at that time a printed edition of the Greek New Testament in existence which could be 'revised and improved' (Erasmus' was the first, apart from the New Testament part of the Complutensian Polyglot, which had already come from the press in 1514 , but was not published until about I522), these words could hardly refer to a Greek text. They mean: here you have a New Testament, obviously in the language in which it was current, Latin, but in improved revised form, i.e. no longer in the generally current Vulgate version. This interpretation is not contradicted, but confirmed, by the following phrase non solum ad Graecam veritatem, verumetiam ad multorum utriusque linguae codicum. The norms for the revised and improved version offered here were the original Greek text and both Latin and Greek manuscripts. ${ }^{6}$ Now Erasmus was well aware that it would be a mockery of all criticism to revise the Greek text of the New Testament from Latin manuscripts. ${ }^{7}$ The norm (Latin and Greek manuscripts) can therefore only have been the norm for the edition of a Latin form of the text. The phrase ad Graecam veritatem also points in this direction. We can illustrate this from some analogous turns of phrase in Erasmus. In the Apolog $\imath a^{8}$ preceding his Novum Instrumentum Erasmus says 'Hieronymus Vetus et Novum Instrumentum . . . ad Hebraeam et Graecam veritatem instauravit'. The instauratio of which he speaks means 'giving a new form to' the text, not a Hebrew or Greek recension, which Jerome

5 Erasmus chose the word Instrumentum in the title because it conveyed better than Testamentum the idea of a decision put down in writing. testamentum could also mean an agreement without a written record. He knew of the alternative wording from Jerome and Augustine, see his justification of the term in $E p$ i 858,11 519-36, in P S Allen and $\mathrm{H}$ M Allen, eds, Opus Epistolarum Des. Erasm Roterodami, v11 (Oxford, I928) (I cite the letters of Erasmus hereafter merely by $E p$ and their number in Allen, and in some cases by line). H Holeczek is mistaken in his Humanistische Bibelphilologie als Reformproblem bet Erasmus von Rotterdam, Thomas More und Willzam Tyndale (Leiden, i975), p I I4, in explainıng the word mstrumentum in the title of Erasmus' first edition of the New Testament as 'Hilfsmittel zum Bibelstudium'. Equaliy mistaken, in my view, is T H L Parker's explanation in Calvin's Nerv Testament Commentares (London, I971), p 93. 'Instrument means here "covenant".'

- It is strange how Erasmus here distinguishes between the Gi eek text on the one hand and Greek and Latın manuscripts on the other, as if the text was a separate entity, independent of the manuscripts

7 See, for example, his Apolog. resp Iac Lop Stun, ASD (by which the new edition of the Opera Omnia (Amsterdam and Oxford, I $969^{-}$), is meant), ix, 2, p. I66, ll 51-3 'Bellum erit vero, si praepostere Graecam lectıonem c Latına castigabımus, hoc est, s1 luxta Graecorum proverbium currus bovem aget' $\mathrm{Cf} A S D, 1 \mathrm{x}, 2$, p. 1 88, 11. 425-35. That Erasmus, forced or led astray by the unhappy condition of his Gi eek manuscripts, sometimes adapted his Greek text to the Vulgate, is another story

${ }^{8}$ Ed. H Holborn, Desiderius Erasmus Roterodamus, Ausgewahlte Werke (Munıch, I933), p. 167 . 
never made. It can only refer to Jerome's translation of the Hebrew and Greek texts into Latin. In the Methodus Erasmus speaks of Jerome's revision of the gospels in Latin, now a part of the Vulgate, as 'evangelia ad Graecam veritatem emendata'. ${ }^{9}$ And in his previously mentioned Apologia Erasmus says that he had produced his improved Latin version of the New Testament 'ad Graecae originis fidem examinatis exemplaribus Latinis': by collating Latin manuscripts with the Greek basic text. ${ }^{10}$ In all these cases the phrase 'according to the Greek original text' does not refer to the criterion for the establishment of a Greek text but to the norm by which a Latin translation is made or revised. The passages cited make it clear that Erasmus meant by the phrase 'ad Graecam veritatem' only the norm by which he revised and edited, and not the language into which, but that from which, he translated. Finally, the words 'cum Annotationibus quae lectorem doceant quid qua ratione mutatum sit', are also instructive: the Annotationes are to make clear to the reader what has been changed and why. But . . . 'changed'? What has been changed? Naturally, not the Greek basic text, which must be regarded as incorrupt, pure, and of pristine originality, and which Erasmus wished to protect, so far as possible, from the suspicion of having been altered, or defiled. ${ }^{11}$ No, it was so self-evident for Erasmus that the New Testament of which his Novum Instrumentum was to offer a new text was one in Latin, that he does not say: 'the Annotationes will tell the reader what has been altered in my new translation with respect to the generally accepted Latin translation, the Vulgate'. He is content to say merely: 'what has been altered'. That it was a matter of changes in the Latin form of the New Testament, and that the Novum Instrumentum was in the first place a New Testament in Latin at all, was apparently tacitly assumed and, according to Erasmus, sufficiently clear. So the title of the Novum Instrumentum both in what it says and in what it omits, announces a New Testament in

Ibid, p. 152

10 Ibid., p. 166 . By such collations Erasmus attempted to assemble as many as possible of the variants in the transmission of the Vulgate with the aim of thereby enabling himself, in his own version, to choose those readings which approached closest to the Greek text This method, which was also adopted in the constitution of the text of the Vulgate in the Complutensian Polyglot, is, seen in hindsight, extremely questionable The Greek manuscripts which werc accessible to Erasmus represented a completely different branch, and another stage, of the transmission of the text from the Latin manuscripts he was thus comparing incompatible witnesses.

11 Compare the way in which Daniel Heinsius praised the Greek text in the foreword to the second Leiden Elsevier edition of the Greek New Testament ( I 633) 'Textum ergo habes, nune ab omnbus receptum: in quo nihal immutatum aut corruptum damus.' 
Latin In fact, the title bears no evidence at all that the book contains an edition of the Greek text

A second set of pointers to Erasmus' vision of what the Novum Instrumentum was in essence, is contained in the prefaces In the dedication to pope Leo X, Erasmus presents his work in a statement whose tendency is as follows (Ep 384, $\mathrm{ll}_{42-64}$ ) to achieve the renewal and strengthening of Christian civilization, a deeper acquaintance with the content of the gospels and the epistles is necessary He continues

I saw that the salutary teaching contained in the New Testament writings is drawn in much purer and livelier form from the sources themselves, the very fountains themselves, than from pools and backwaters Therefore I have revised the New Testament, as it is called, entirely in accordance with the original Greek [ ] We have added our Annotationes in order that firstly they should enlighten the reader as to what has been changed and why, and secondly that they should explain everything which seems complicated, unclear or difficult ${ }^{12}$

In short, what Erasmus announced was in the first place his new translation, based on the Greek, and in the second place his Annotationes which were to justify the new translation's deviations from the Vulgate But Erasmus speaks not a word about offering an edition of the Greek text as well

In his $A$ pologia Erasmus himself explains that his New Testament is specially intended for those who have not had the opportunity to study Greek and Hebrew ${ }^{13} \mathrm{He}$ means my new translation gives the character and the nuance of the Greek so adequately that this Latin translation, with the Annotationes, will put the reader who knows no Greek on the same level as the Greek text does the reader who can read Greek It can hardly be more clearly stated, that the Greek text in the Novum Instrumentum is not the main point, the aim of the work is above all to reveal as much as possible of the Greek text in the phraseology of a new Latin version In this conception, printing the Greek text is largely superfluous, at least, for the user of the Novum Instrumentum the function of the Greek text is considered to be secondary

How Erasmus considered his Novum Instrumentum is even more evident from the Apologia, in which he recommends the study

${ }^{12} E p$ 384, 11 49-53 and 59-62 'cum viderem salutarem illam doctrinam longe purius ac vividius ex ipsis petı venis $\mathrm{cx}$ ipsis haurirı fontıbus, quam ex lacunıs aut rivulıs, Novum (ut vocant) Testamentum universum ad Graecae originıs fidem recognovimus' 'Adrecımus Annotationes nostras, quae primum lectorem doceant quid qua ratione fuerit immutatum, deınde, sı quid alıoqu perplexum, ambiguum aut obscurum, $1 \mathrm{~d}$ explicent atque enodent

1) Holborn, p I 64, 11 i 8-23 
of Greek and Hebrew. In the first place those who know these languages can study the earliest Christian sources and the Bible itself. 'In the second place one can then, if one wishes, compare our work (nostra) and judge it, and only then state one's approval of what we have remarked, or else improve that in which, human as we are, we have perhaps erred from the true meaning of the original text and rendered it inadequately. '14 By 'our work (nostra)' Erasmus can only mean his Latin translation, explained in the Annotationes. He sets it alongside the original, described as 'the true', verum. What he lays before the reader for his approval, and what he thus puts in the centre of his attention, is his own new translation. Let the readers judge, he pleads, whether he has grasped the original, verum, justly and rendered it adequately. The criterion, the Greek text, remains beyond discussion here: the Greek is the norm, but not an object of judgement. The textual form of the Greek is, as an established fact, excluded from discussion from the outset: how else could it serve as norm? But by so doing Erasmus thus makes the Latin translation the pièce de résistance of his edition.

Indeed, the entire Apologia cannot be understood unless one bears in mind that what Erasmus was defending is no more than his new translation into Latin. Such sentences as 'Tantum restituimus quae temporum ac librariorum vitio fuerant depravata' 15 and 'Nos locos aliquot innovavimus, non tam ut elegantius redderemus quam ut dilucidius', ${ }^{16}$ can only refer to the new Latin version of the New Testament which Erasmus offers, just as does his assurance that the current Latin translation remains unscathed by 'nostra castigatio'. ${ }^{17}$ And apart from one brief sentence which will shortly be discussed, this apologia contains no reference to the fact that the work in question will contain an edition of the Greek text. The other forewords, Paraclesis and Methodus, are wholly silent on it.

The introduction to the Annotationes ${ }^{18}$ too makes no reference to the inclusion of an edition of the Greek text in the Novum Instrumentum. The passage in which Erasmus says 'Testamentum quod vocant Novum omni qua licuit diligentia quaque decuit fide recognovimus, idque primum ad Graecam veritatem, ... deinde ad fidem vetustissimorum Latinae linguae codicum, ... postremo ad ... autorum vel citationem vel emendationem'19 refers once again to the new Latin version and not to a recension of the Greek. Because the novitas of this version, as Erasmus rightly feared, would arouse

14 Ibid., p. I65: 'Deinde nostra s1 volent, conferant et expendant atque ita probent, si quid recte monuimus, emendent amice, si quid ut homines aberravimus a vero et minus assecuti sumus. ...
15 Ibid, p. 165.
16 Ibid., p. I67.
17 Ibid., p. I 68.
${ }^{18}$ Ep 373.
19 Ep. 373, 11. I2-32. 
serious resistance, he states that he will defend and justify his improved version (nostra emendatio, i.e. better than the Vulgate) in the Annotationes. ${ }^{20} \mathrm{He}$ says nothing of the Greek edition, even when he speaks of the characteristic 'fragrance' of the language of the gospels, the vis ac proprietas of that language, which can only be appreciated in the Greek itself. ${ }^{21}$ In short, it can scarcely be argued that Erasmus pretended to give an edition of the Greek text in his Novum Instrumentum. His pretensions were different: to render the Greek as well as possible in a new translation which met the demands of the times, and whose Latin was purer, clearer, and more correct than that of the Vulgate. ${ }^{22}$

In his statements on the relationship between the Latin and Greek texts included in his work, Erasmus offers us a third set of indications as to his aims in the Novum Instrumentum. ${ }^{23}$ In his Apologia he requests the reader not to condemn at once every novelty which strikes him in the Latin translation and to reject it, but to test it first against the Greek. Then follows the sentence to which I referred: 'quod quo promptius esset, illa [sc. Graeca] e regione adiecimus': 'and so to facilitate this [the comparison], we have set the Greek directly alongside.' ${ }^{24}$ This is the only hint which Erasmus gives as to the significance of the Greek text, in his prefaces, but it speaks volumes. The Greek has been 'added'(!) so that the reader can convince himself that the Latin translation does not contain any rash innovations, but is solidly based. The Greek is thus intended to serve as a justification of the Latin. Viewed in this light the Greek has a prominent role, but one still subordinate to the Latin: it must authorize the vulnerable Latin translation. Clearly, the Latin translation is the main point and the Greek is added as accompanying and supporting documentation.

${ }^{20} \operatorname{Ep} 373,1.36$.

21 Ep. 373, 11, 167-74

${ }^{22}$ In $E p .373,11.6_{1-3}$, Erasmus gave the object of his translation as the removal of soloectsm and the cultivation of sermonts elegantia in such a way that its simplicitas would not be lost. 'Verum non hoc egimus ut sermo politior esset, sed ut emendatior ac dilucidior', Il i 86-8, all the comparisons being with the Vulgate I confine myself to these citations from Erasmus, chosen from many avalable. He wished the language of the New Testament to match the consuetudo of the probatr auctores In practice this meant that he wanted to make its vocabulary and syntax reflect that of Cicero, and was less Itkely to accept the phenomena of late or Christian Latin This position implied a carefully considered view of, and attitude to, culture the world had outgrown barbarism, the church had attained a certain splendor, and it was time for the Bible to speak, not haltingly and stammeringly, but in casto puroque sermone See H. J. de Jonge, 'The Character of Erasmus' Translation of the N.T ', Fournal of Medieval and Renatssance Studies, I 4 I (1984) (in the press).

23 I pass over the fact that in the fourth edition (Basle, I 527) Erasmus included the Vulgate alongside his own translation and the Greek text, to take some of the wind out of his critics' sails.

${ }^{24}$ Holborn, p. 170. 
That this was Erasmus' intention is also evident from the phrasing in which he lists, in a letter of eighteen months before, the works with which he is occupied or intending to publish. The Adagia, he writes, are in the press, and "what remains is my translation of the New Testament with the Greek alongside, and with my comments on that work': 'Superest Novum Testamentum a me versum et e regione Graecum, una cum nostris in illud annotamentis. ${ }^{25}$ In principle Erasmus saw his edition of the New Testament as a 'Novum 'Testamentum a me versum' to which the Greek text and the annotations were added. That the Greek served to buttress the correctness of the Latin translation, and that the Greek therefore had to be placed alongside the Latin 'so that the Latin could be compared more easily with the Greek', was also known to the representative of the printer Froben, Nic. Gerbell, who in I 5 I 5 still had serious objections to the lay-out desired by Erasmus ${ }^{26}$ Gerbell wanted to print the Greek text separately, not alongside the Latin, so that the Greek could be bound and sold independently of the Latin. Erasmus was bitterly opposed to this. It is characteristic that Gerbell himself soon published the Greek text taken from Erasmus' second edition, without the Latin version, with another printer and publisher: the first separate edition of the Greek New Testament ever published (Hagenoae 1521). Implicit in such an edition destined for the Greek-reading public alone was an idea of what the New Testament must be, which Erasmus did not share. He thought of a broader circle of readers of Latin, who would only wish to refer to the Greek in the second place.

Erasmus also gave his opinions on the relationship of Greek and Latin texts in an important and well-known letter of I $_{5} I_{5}$, in which he defended his plan of editing the New Testament against the Louvain theologian Martinus Dorpius, who had hoped to dissuade him from undertaking the edition. In this letter Erasmus announced what was to be looked for in this edition as follows: 'universum Testamentum Novum ad Graecorum exemplaria vertimus, additis e regione Graecis quo cuivis promptum sit conferre. ${ }^{27}$ What Erasmus was to offer is thus: the whole New Testament in a translation from the Greek; the Greek was to be printed alongside as an addition (additis) for comparison.

In 15il 8 Erasmus was preparing a second edition of his New Testament. He considered it desirable that a papal approval should be included in the book in order to ward off the venomous criticism

${ }^{25}$ Ep. 305, 11. 222-4.

26 Ep. 352, 11, 40-I : 'Possem multa obiicere, unum tantum dispicio quod tu possis obtrudere, scilicet ut facilius Latina Graecis conferantur.'

${ }^{27}$ Ep. 337, $11.862-4$. 
which his work seemed to draw from some quarters In the letter in which he politely requested the approbation of the pope, he had naturally to give a short but representative description of the nature and purpose of the work in question $H_{1}$ description begins as follows 'After comparing a great number of Greek manuscripts we have followed what seemed to us the purest reading and translated it into Latın' 'Collatis multıs Graecorum exemplar1bus, quod syncerissimum videbatur secutı, vertımus Latine '28 The first thing which Erasmus has to say of his New Testament is that he presented a new translation into Latın, based on Greek manuscripts

Fourthly, that the aim of the Novum Instrumentum was not originally an edition of the Greek New Testament, is evident from what is known of the preparations for the work It is established, and generally accepted, that Erasmus had been working on the text of the New Testament since 1504, and had been studying Greek manuscripts for this purpose In the years ${ }_{1502-4}$ he had made himself familiar with Greek ${ }^{29} \mathrm{H}_{1}$ goal now was to make a new Latin translation on the basis of Greek manuscripts The Annotationes in Novum Testamentum of Valla, which he had found in I 504 and published in I505, had shown the possibility and the desirability of such a new translation By i 506 at the latest Erasmus had completed his new translation of Paul's Epistles, and not later than 1509 he had made a new version of the Gospels those years are the dates borne by the colophons of the farr copies in which his translation is contained and which are preserved in London and Cambridge ${ }^{30} \mathrm{~A}$ codex which is approximately contemporary with these manuscripts contains his Latin translation of the integral

28 $E p \quad 860,11$ 32-3 Honesty requires us to say that immedately afterwards Erasmus writes that he has added his Latin translation to the Greek text, but this presentation of affarrs is exceptional normally he puts it the other way round, that the Greek had been added to the Latın And in $E p 860$ the Greek plays no part all the attention is focused on the Latin translation and the Annotatrones

${ }^{29}$ Ep $18 \mathrm{I}, 11$ 34-6 He had already begun to learn Greek in Paris

${ }_{30}$ MSS London, Brit Libr I Reg E $v_{1-2}$ (Luke and John, dated ${ }_{5} 506$, and all the Epıstles, dated 1509), Cambridge, Unıv Lubr, Dd vı 3 (Matthew and Mark, dated I 509) The manuscripts were correctly listed by P S Allen, Opus Epistolarum, 11, p i 82, in Erasmus en zijn tijd (exhibition catalogue) (Rotterdam, 1969), 1, nos 104 and 106, and by J B Trapp, 'Pieter Meghen 1466/7-1540 Scribe and Courier', Erasmus in English i I (198I-2), pp 28-35, see pp 30-3 (with platcs) Henrı Gibaud, of Angers, has recently edited Erasmus' translation of the New Testament as contained in the London, Cambridge, and Oxford (sec next note) manuscripts It is basically the same as the one printed in the Novum Instrumentum and the Novum Testamentum, but there are differences, see H Gibaud, Un inedit d'Erasme la premere version du Nouveau Testament (doctoral thcsis Tours, March 1982) (Angers, 1982) 
New Testament (now in Oxford) ${ }^{31}$ With interruptions for other activities Erasmus continued to work on what he called his castigatio, $1 \mathrm{e}$ his improved Latin text of the New Testament, purified by reference to the Greek manuscripts In I5I5 he announced 'Ex Graecorum et antiquorum codicum collatione castigavi totum Novum Testamentum, et supra mille loca annotavi non sine fructu $\quad{ }^{\prime 32}$ His comparison of Greek manuscripts seems thus also to have resulted in Annotationes, in which he indicated the places where the Vulgate farled to render the Greek manuscripts adequately Erasmus had been working for about ten years on such a renewed Latin version, based on Greek manuscripts, when in August-September I 5 I 4 his plan for a Greek-Latin edition began to take shape ${ }^{33}$ But how long had he been working on a Greek recension then?

Unfortunately this latter question is involved in serious misconceptions for which the great Allen must bear a share of the blame He wrote 'At what point this decision [1 e to publish the Greek text] was made is not clear perhaps during his residence in England, where he was certanly at work upon the New Testament in I 5 I 2-I 5 I $3^{\prime 34}$ and 'his first recension of the Greek text took place in England, probably in I 5 I $2-15$ I $3{ }^{\prime 35}$ What Allen adduced in support of these assumptions, however, does not refer to the Greek but to the Latin version ${ }^{36}$ There is no trace of any indication that Erasmus, when he journeyed from England to Basle in July I 5 I 4 , had yet prepared a recension of the Greek text of the New Testament In Basle he certainly did not possess such a recension of his own in August I 5 I 4, for he had to ask Reuchlin to put a Greek manuscript of the entire New Testament except Revelation, at the disposal of the printer Froben ${ }^{37}$ In the event, it was not this

31 MS Oxford, Corpus Christi College, F 4 9-ro Coxe r 3, 4 (whole Ncw Testament) See P S Allen, Opus Eptstolarum, 11, p i 82, Erasmus en zitn tyd, 1, no 105 , and 11 , plates on pp I24-5

${ }^{32} \mathrm{EP}$ 296, of 8 July I 5 14, to Scrvatius Rogerus, 11 i $55-7$

3 The earliest sign of this intention is Ep 300, of August I 5 14, to Reuchlin,

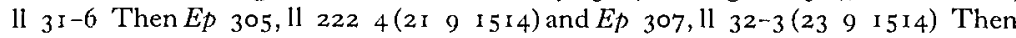
we learn nothing more until Froben asks about the edition in April i 515 ( Ep 328 and $\left.33^{\circ}\right)$

34 Opus Eptstolanum, 11, p i 82

3) Ibid, p I64 H Holeczek, Humantstrsche Bıbelphilologie (Leiden, I975), pp 99 and Ior, thinks that Erasmus had already conceived the idea of editıng the Greek New Testament in 1505 under the influence of Valla's Annotationes This view lacks any support

${ }^{36} E p$ 264, 11 I3-I4 'Absolvam castigationem Nov1 Testament1', Ep 270, 1 58, 'Absolvi collationem Novi Testament1', Resp ad iuv gerontodid, $L B$ 1x, $986 \mathrm{EF}$ 'in codice, unde contul in Anglia 'and 'collationıs negotium peregeram in Anglia' ${ }^{*}$ EP 300, $1133-6$, with Allen's note 
manuscript (now Basle U B, A IV 2, minuscule I eap) which went to the printer but two others (now Basle U B, A N IV I, minuscule $2^{\mathrm{e}}$ and $\mathrm{U} \mathrm{B}, \mathrm{A} \mathrm{N}$ IV 4 , minuscule $2^{\mathrm{dp}}$ ), ${ }^{38}$ both twelfth century, as well as a copy made for the purpose of another twelfthcentury manuscript of Revelation (now Schloss Harburg, OttıngenWallersteinsche Bibliothek, I, I, $4^{\circ} \mathrm{I}$, minuscule $\mathrm{I}^{\mathrm{r}}$ ) From the fact that Erasmus gave these manuscripts, the first two of them somewhat corrected by four other known manuscripts, to the printer as copy, it is again clear that he cannot have brought any manuscript of a recension of the Greek New 'Testament made by himself, with him on the visit which he made from Basle to England in April to July 15 I5 The truth is that he never made any such recension Allen is therefore wrong to assert that Erasmus had made a first recension in England, for which he used four manuscripts, and a second in Basle The passage on which this assertion is based is in the Apologia and reads 'Nos in prima recognitione quattuor Graecıs (sc exemplarıbus) adiut sumus '39 The recognitio referred to here is however, not a recension of the Greek text, but a revision of the Latin, $1 \mathrm{e}$ the new Latin translation the same recognitio which is announced on the title page of the Novum Instrumentum True, it is known that Erasmus used not four, but seven Greek manuscripts, for the edition of I 5 I 6 three which went to the printer and four which he merely collated In the Apologia, however, he means that he only used four of these seven ${ }^{40}$ for the recognitio of the Latin text

Neither in I5I4 when he made plans for a Graeco-Latin edition of the New Testament, nor in 15 I 5 when this edition was sent to the press, had Erasmus prepared any form of Greek recension of his own The new Latin text, on the other hand, had been his occupation for the last ten years If we take these facts into account, we can scarcely maintain that the Novum Instrumentum was in the first place an edition of the Greek New Testament

Fifthly, numerous reactions of Erasmus' contemporaries also

${ }^{38}$ On min $2^{\text {e }}$ see K W Clark, 'Observations on the Erasmian notes in Codex 2' in K W Clark, The Gentıle Bras and Other Essays (Suppl to Novum Testamentum 54) (Leiden, 1980), pp 165-72

${ }^{39}$ Holborn, p 166 Allen, Opus Eptstolarum, 11, p I64, takes this sentence to refer to a Greek recension made in England But prima must refer to the first edition of the Novum Instrumentum, as is evident from the enumeration of the later editions which follows immediately afterwards (see Holborn, $p$ i66)

40 These seven manuscripts, are, in the Gregory numbering usual for New Testamcnt manuscripts $\mathrm{I}^{\mathrm{eap}}, 2^{\mathrm{e}}, 8 \mathrm{i} 7$ for the Gospels, $\mathbf{2}^{\mathrm{dp}}, 4^{\mathrm{ap}}$, and $7^{\mathrm{p}}$ for the Acts and the Epistles, and $\mathrm{I}^{\mathrm{r}}$ for Revelation Those sent to the press were $2^{\mathrm{e}}, 2^{\mathrm{ap}}$, and a new transcript of $I^{r}$, which together made up all the books of the New Testament Which four Erasmus used for his Latin recognttio cannot be discovered 
make it clear that it was their view, as well as that of Erasmus, that the Novum Instrumentum was in the first instance a new version of the New Testament in Latin Both the praise and the criticism of contemporaries was concerned mainly with the Latin version, and with Erasmus' comments, while the Greek text received little attention It was the translation which gave many a new insight into the New Testament, or in the opinion of others, made it impossible to see the New Testament rightly Various authors have already established that attention was centred mainly on the Latın translation ${ }^{41} \mathrm{I}$ do not need to spend much time on this Among the enthusiastic admirers we find, for example, Richard Foxe, bishop of Winchester, who as Thomas More informs us $^{42}$ declared to a numerous assembly of prominent persons, that for him Erasmus' translation of the New Testament was worth as much as ten commentaries, so much light did it shed for him What made so many opponents furious was that Erasmus had taken it upon himself, on his own authority, to change the Latın biblical text, hallowed by its thousand years of use, to falsify it and to replace it by something of his own manufacture We should recall that the Vulgate was the text on whose phraseology, phllosophy, theology, and law had been founded for centuries past Whoever attacked that phraseology or replaced it with another was undermining the foundations of society For example, by altering the word sacramentum to mysterium in Eph v 32, Erasmus, so his critics argued, ${ }^{43}$ had attacked the sacramental status of marriage Behind the fury which was poured out on Erasmus' Novum Instrumentum lay anxiety over the serious consequences which the removal of the trusted biblical proof-texts could have for science, law, and morality and

${ }^{41}$ For example, W Schwarz, Principles and Problems of Bublucal Translation (Cambridge, I 955), p I63, B Hall, 'Erasmus biblical scholar and reformer' in 'T A Dorey (ed), Erasmus (London, 1970), pp 8I-II3, see p 98, G B Winkler in his introduction to Erasmus of Rotterdam, In Novum Testamentum Praefationes, Uebersetzt, eingeleitet und mit Anmerkungen versehen von $G$ B Winkler (Darmstadt, 1967), p xvin The only authors known to me who have suspected that the Novum Instrumentum was mainly concerned with the new Latin translation, are Hall in his study mentioned above, and $\mathrm{H}$ J Genthe, Kleine Geschachte der neutestamentlichen Wissenschaft (Gottıngen, i977), pp I 3 and 16

42 More to Erasmus, 15 December $5_{516, E p} 502,11$ 19-23 Another significant, typical and instructivc example of how Erasmus' New Tcstament was undcrstood is the testimony of the St Gallen Lutheran Johannes Kessler (Sabbata ed R Schoch (St Gallen, r 902), p 87), who, in I 524, praised Erasmus' New Testament as a Latın translation in the following terms 'das nuw Testament nach kriechischem text warhaft in latin verdolmetst, daruss vil nutzes und besser verstand erwachscn ist' Kessler does not tell us that Erasmus edition includes the Greek text I wish to thank Dr J Trapman of The Hague for bringing this passage to my attention

43 Among others by Ld Lee (see $L B$ ix, pp 225-8), Jac Lopis Stunica (see $L B$ ix, 338) and S Caranza (see $L B$ 1x, pp 429-32) 
ultimately for the existence of society itself. The work with which Erasmus' most competent and most tenacious opponent, the Spaniard Jacobus Lopis Stunica, opened fire on the Novum Instrumentum in 1520 set itself the goal of defending the Vulgate against Erasmus' attacks on it; his work is entitled Annotationes contra Erasmum Roterodamum in defensionem tralationis Novi Testamenti (Alcala, 1520). By tralatio [sic] was meant: the only translation which had any claim to be recognized: the Vulgate. Against the publication of the Greek text Stunica made no objection. How could he? He himself had collaborated on the edition of the Complutensian Polyglot in which the Greek text of the New Testament had been printed for the first time. What really aroused Stunica's anger was the threat which Erasmus' Novum Instrumentum contained for the Vulgate. It is a misunderstanding of Stunica's motives to explain, as Pfeiffer does, ${ }^{44}$ his attacks on Erasmus as jealousy of the success of Erasmus' edition, and to ignore Stunica's anger at the damage which Erasmus had inflicted on the authority and position of the Vulgate.

Sixthly, we must not forget that Erasmus regarded his edition of the New Testament as part of a grandly conceived plan for the renewal of church, culture, and society. In the Paraclesis he asserts that if the clergy, the princes, and the teachers would base their doctrine on the gospels instead of on Aristotle, Europe would not be continually troubled by persistent warfare on all sides and there would not be so many disputes in church and state. The renewal which Erasmus had in mind demanded that the New Testament should receive a central place in education. As his contribution to this renewal and to the re-establishment and consolidation of Europe's spiritual force, Erasmus, so he wrote to Leo $X,{ }^{45}$ 'had revised the New Testament in accordance with the Greek', i.e. had put it into a new Latin form based on the Greek. Now it is selfevident that Erasmus could not contribute much to the accomplishment of this ideal by means of an edition in Greek. Only a very few would have been able to read it. Therefore, he says that he has prepared his revised Latin version to help achieve his desired goal. He wished the New Testament to be read and studied by large groups of people, for whom adequate knowledge of Greek was not attainable and for whom a Latin translation would thus be indispensable. But the Vulgate was not suitable for them. In his eyes it was an inadequate translation couched in careless, unclassical, and often incomprehensible Latin; and, moreover, it had

${ }^{44}$ See R. Pfeiffer, History of Classical Scholarship from 1300 to 1850 (Oxford, 1976), p. 94 .

${ }_{45}$ In the dedication of the Novum Instrumentum to Leo: Ep. $3^{84}$, 1l. 49-53. 
been corruptly transmitted To bring many people to read the New Testament a new translation made directly from the Greek, into correct and easily comprehensible Latin, was required That was what Erasmus was now offering in his Novum Instrumentum

Finally, it is extremely revealing to read how Erasmus spoke of his edition in a letter to Joh Botzheim in $1524^{46}$ In this letter Erasmus gave a summary of the titles he wished to see included in a possible edition of his collected works He also indicated how they were to be divided among the eight tom Testament was to take up the whole of volume 6 Erasmus put it thus 'Sextus designetur Novo Testamento a nobis verso, et nostris in idem Annotationibus '17 Since he remarks that this tomus, on account of its bulk, might probably be best divided into two volumina (like the three editions which had already appeared of the Novum Instrumentum and Novum Testamentum), Erasmus undoubtedly wished the Greek text to be included in his Opera Omnia, which is what happened None the less he does not mention the Greek text in the above reference to the planned edition For him it was an edition of the New Testament in Latin 'Novum 'Testamentum a nobis versum', with the Annotationes, while the Greek was fundamentally a quantite negligeable

The forgoing argument has far-reaching consequences for the evaluation not only of Erasmus' Novum Instrumentum and Novum Testamentum as a whole, but for the edition of the Greek text included in it in particular

It is incorrect to speak of the Novum Instrumentum and its reeditions as 'Erasmus' edition of the Greek New 'Testament' and to omit to mention Erasmus' real concern the Latin translation on which he had worked for ten years Pferffer and Reynolds-Wilson, who say not a word of the Latin translation, are not the only ones to make this error of judgement E J Kenney, too, fails to refer to the Latin translation which was the kernel of Erasmus' edition, in his paragraphs on Erasmus, ${ }^{48}$ and the same is true of others ${ }^{49}$

More widespread is the misconception that Erasmus' editions of the New Testament were in principle editions of the Greek text,

ir Ep 1, in Allen, Opus Eptstolarum, 1, p 4r, 11 4-7

${ }^{47}$ Ep 1, loc cit , ll 4-5 The title of this article has been taken from this passage

${ }^{48} \mathrm{C}$ J Kenney, The Classical Text Aspects of Editing in the Age of the Printed Book (Berkeley Los Angeles London, 1974), pp 50-1 and 76-7

19 For example, S Berger, La bible au XVIe siecle (Par1s, 1879) (reprint Geneva, 1969), pp 54-69, S Timpanaro, La genesz del metodo del Lachmann (Padova $1981^{2}$ ), p 17 
to which a Latın version had been added as something of less importance This reversal of the truth is the usual presentation of affairs in handbooks on the textual history of the New Testament, such as those of Nestle ${ }^{50}$ and Metzger, ${ }^{51}$ and in monographs on Erasmus' life and works Preserved Smith, for example, discusses the Novum Instrumentum as in principle a 'Greek Testament'52 and as an edition of the 'Greek text' which was accompanied by a 'Latin version' 53 This misunderstanding is accepted and repeated in a recent study by J. Hadot devoted to Erasmus' textual criticism of the New Testament Hadot says, referring to Erasmus, 'En réalité, Il a luı-même réalısé une traduction latıne, très élegante et très savante, mas son but veritable est de donner un texte grec du Nouveau Testament pour revenır ad graecam veritatem. ${ }^{51}$ The 'réalité' is precisely the opposite

In particular, my interpretation of Erasmus' edition of the New Testament will necessarily have consequences for our verdict on his editions of the Greek text. In itself it is deserving of the highest praise that Erasmus was the first to make the New Testament widely accessible in the original language and this praise will remain pre-eminent That does not, however, detract from the fact that his editions of the Greek text leave much to be desired, even though much of the criticism of them is historically misplaced I shall refer briefly to the most important observations which are usually made on his editions of the Greek text

I (a) It was based on recent manuscripts, (b) which Erasmus nevertheless described as vetustissim

2 It was founded on Greek manuscripts of the inferior Byzantine textual type, instead of on the Egyptian text type which is now considered superior

3 (a) At many places where the Greek manuscripts seemed to lack words or phrases which were found in the Latin Vulgate, Erasmus included retroversions from the Vulgate in his Greek edition sometimes words, sometimes whole sentences, he did this not only where the difference between the Greek and the Vulgate was the result of divergent textual traditions, but also $(b)$ at the end

${ }^{\circ 0} \mathrm{~Eb}$ Nestle, Einfuhrung in das griechusche NT (Gottıngen, 1909'), pp 3-6

${ }^{51}$ B M Metzger, The Text of the $N T$ (Oxford, I $968^{2}$ ), pp 98-101, similarly, $\mathrm{K}$ and $\mathrm{B}$ Aland, Der Text des $N T$ (Stuttgart, i 982 ), $\mathrm{p}$ I 4

${ }^{52}$ Preserved Smith, Erasmus A Study of his Life, Ideals and Place in History (New York, I 923) (reprint I 962), P I 74

s3 Ibid, p i 63 A stmilar view was held by Joseph Coppens, 'Erasme exegete', Ephemendes Theologicae Lovanienses, 54 (1978), pp I $30-3$

¿4 J Hadot, 'La critique textuelle dans l'edition du Nouveau Testament d'Erasme', in Colloqua Erasmiana Turonensıa, 1 (Parıs, 1972), (De Petrarque a Descartes 24), pp 749-60, see p 757 
of Revelation, where in his Greek manuscript ( $\mathrm{min} \mathrm{I}^{\mathrm{r}}$ ) the text was defective, lacking six verses Erasmus retranslated them from the Vulgate (though he did state that this was what he had done)

4 Several words of these retranslations from the Vulgate (e g Rev xx11 2I $\dot{v} \mu \hat{\omega} \nu$ ) were never corrected or removed by Erasmus in accordance with authentic Greek textual witnesses, even after he had access to the Complutensian Polyglot in 1522

5 The Greek text continually differs, for no reason, from the manuscript on which it is based, and thus contains readings without any basis in the textual tradition

6 The text contains hundreds of printer's errors

7 It includes many spelling errors, taken over from the manuscripts which had been much too carelessly corrected before they were given to the printer, especially numerous iotacistic readings, faults in the notation of breathings, 1ota subscripta, and nu euphonica

8 For Revelation, Erasmus gave the printer as his copy, a transcript of a manuscript in which the actual text is embedded in the commentary of Andreas of Caesarea (c600) In the transcript and thus also in the printed text, words of Andreas have occasionally found their way into the biblical text

I cannot go into all these points in detail here I shall just say this the 'Vorlagen' from which the Greek texts were printed were three manuscripts of the twelfth century They were then four hundred years old and indeed of respectable antiquity, in view of the then small number of avalable Greek manuscripts, uncials in particular ${ }^{55}$ If Erasmus had taken more time (the whole Novum Instrumentum was printed in six months, in which time the entire Greek text and the greater part of the Annotationes had to be prepared) he could naturally have found other manuscripts Because of the haste into which he allowed Froben to drive hım, he made himself dependent on the manuscript collection of Johannes Stojković de Ragusıo, which happened to be in Basle ${ }^{56}$ But we

2. For a complaint from 1517 of the scarcity of Greek manuscripts in particular, see $E p \quad 520,11$ 75-6 It is striking that Erasmus prepared for the press three of the oldest of the seven manuscripts avarlable to him, but only collated the youngest (the fifteenth-century minuscules $4^{a p}$ and $8 \mathrm{r} 7$ ) Of course he was aware of the difference That he dated the twelfth-century manuscript of which he made a copy for the edition of Revelation as 'possibly from the time of the Apostles' (Annot in N T, ad Rev $1117, L B$ v1, rog8F), was perhaps a result of the fact that the commentary of Andreas of Caesarea, in which the biblical text is embedded in this manuscript, bears the name of Ilippolytus of Rome, $c$ A D 200-50

if R W Hunt, 'Greek MSS in the Bodleian Library from the collection of John Stojkovıc of Ragusa', in Studia patristıca, vi1 1, ed F L Cross (= Texte und Untersuchungen, 92) (Berin, I 966), pp 75-82, E J Kenney, The Classical Text, p 76 
must also bear in mind that if Erasmus had had more time and had found manuscripts of the now preferable Egyptian type, he would certainly not have used them On the contrary, he regarded the older Egyptian text form as having been deliberately brought into conformity with the Latin Vulgate, and thus as corrupt and to be rejected ${ }^{57}$ If this (false) theory is borne in mind, we can only expect Erasmus to have edited the Byzantine text

But the main point to be remembered is that the greater part of the criticism levelled against the Novum Instrumentum and its Greek text, starts from the erroneous assumption that it was Erasmus' intention to prepare a separate edition of the Greek text The true purpose of the Greek text which he offered is almost always missed The aim of this text was to give the reader of the Latin text column, the opportunity to check whether the surprising and startling new phrasing of the new translation was really based on the Greek This Greek was designed as an aid to the verification of the accuracy of the unfamiliar Latin expressions It is not necessary to excuse Erasmus for his carelessness, but it is important, and reason demands it, to try to understand this remarkable thoughtlessness For his purpose a not too scrupulously prepared Greek text was adequate The quality of the edition of the Greek made little difference, as long as it could serve to justify the choice of wording and phraseology of the Latin translation That was its function Thus it was that Erasmus sometimes introduced something into the Greek which had not been there before, but which was necessary to cover the Latin (and was thus dictated by the Vulgate) Ultimately, compared to the literary and linguistic quality of the Latin translation, the textual accuracy of the Greek edition was a matter of little moment to him It was not the textual criticism of the Greek, but the presence of the Greek at all, with which he was concerned As long as the Greek proved that his version, his Latin wording, was not plucked out of thin air, it was sufficient He desired no more The edition of the Greek remained a parergon, an addition which had been decided on in a late stage of the work, at the service of the translation

We must not ascribe to Erasmus' Greek text pretensions which he did not have, nor judge him by goals which he did not share, and ignore his true aims The usual criticism errs in omitting to bear in mind that this text was not intended to be an independently published edition It is of great significance that Erasmus never brought out the Greek column in separate editions, though he did allow the Latin translation to be printed independently on

57 For this theory of Erasmus see H J de Jonge, 'Erasmus and the Comma Johanneum', Ephemerides Theologicae Lovantenses, 56 (1980), pp 381-9, esp 387-9 
numerous occasions. He did so at first perhaps with some reluctance but soon with growing approval, as is evident from the four separate prefaces which he wrote for these separate Latin editions. ${ }^{58}$

It is clear how this misunderstanding of Erasmus' purpose and the now current inaccurate approach to his Greek text has arisen (we must try not only to understand the shortcomings of Erasmus but also those of his critics). When, in the later seventeenth and eighteenth centuries Erasmus' Novum Instrumentum became the subject of historical research and writing, his editions of the New Testament were no longer works in current use and had not been so for many years. His translation belonged to the past. There were now translations in the vernacular: those of Luther, King James, and the Dutch States General, as well as more recent Latin versions. Erasmus' translation was no longer of much interest to those who described the history of the text of the New Testament (J. Mills, I645-1707, and J. J. Wettstein, I693-I754). Their attention was focused on his Greek text. The Greek text of the New Testament had increasingly gained a firm position, in the noncatholic countries of Europe, in scholarship and teaching. For those who studied the textual history of the New 'Testament, Erasmus' Greek text, the first to appear in print, was more interesting than his translation. For them, the side issue became the main one and vice versa. Others who did not consider themselves competent to have an opinion of their own, made themselves dependent on these textual historians. The current opinion on Erasmus' New Testament is in essence that of Wettstem. ${ }^{59} \mathrm{It}$ is striking and by no means incidental that the author of a Swedish doctoral dissertation on 'Erasmus' merits in the field of literature' ${ }^{60}$ dating from 1743 , that is, from the time preceding the appearance of Wettstein's New Testament $(\mathrm{I} 75 \mathrm{I}-2)$, found that Erasmus, 'propter interpretationem [1.e. his translation] librorum $\mathrm{N}$. Testamenti magni utique est faciendus', but did not find it worthwhile to make any mention of Erasmus' Greek text edition or annotations. This assessment may now seem to be somewhat strange, but from a historical point of view it is more adequate than the assessment of many modern critics who speak of Erasmus' Greek text edition as unsatisfactory without saying a word about his translation.

For twentieth-century philologists, who are accustomed to study

58 See Allen's introduction to $E p$ ro го.

59 J J Wetstenıs, Novum Testamentum Graecum, 1-11 (Amstelaedam1, 175 I-2), see I, Prolegomena, pp. 1 20-7 Wettstem was already concentrating entirely on the Greek text and falled to see its supporting function with respect to the Latin text

60 P P Ekwall, Dissertatio hastorico-literana, merta Erasm Roterodam in literas humantores delineans (Upsalıae, I743), p 16. 
their texts in the original languages, it has clearly become impossible to imagine that Erasmus still saw the New Testament in the first place as a Latin book, and not a Greek one. Yet it is true that although Erasmus regarded the Greek text as the norm for his translation, he continued to think of the New Testament as, in principle, a Latin book. If we look at Erasmus' views in the context of his own time, then this is almost self-evident. Erasmus thought not in national but in European terms. He welcomed vernacular translations with great enthusiasm, but they could mean nothing for Europe as a whole. Knowledge of Greek was thinly spread. Latin was, as a result, the only language in which the Bible could play a role in the culture of Europe. Such a Latin Bible existed in the Vulgate, but Erasmus wanted one in better Latin: in that he was a humanist. Although he accepted the Greek text as philological norm for this Latin translation, he still believed that for his time, the Bible had to be a book in Latin. In this view, the Greek text had a limited and purely grammatical authority, to be exercised at the desks of a small number of scholars. But Erasmus attributed the functions which the New Testament was to perform in society exclusively to the Latin text and not to the Greek. Real influence could only be exercised by a Latin text. The Latin form of the Bible therefore remained the most important one for Erasmus. In this last point he did not differ from such contemporaries as the editors of the Complutensian Polyglot. They placed Jerome's Latin translation of the Old Testament between the Hebrew on one side and the Greek on the other. In their foreword, they justified the central position of the Latin with a remarkable reference to the unique relationship between the Latin tradition and the truth: 'Mediam autem inter has Latinam beati Hieronymi translationem, velut inter synagogam et Orientalem Ecclesiam, posuimus, tanquam duos hinc et inde latrones, medium autem Iesum, hoc est Romanam sive Latinam ecclesiam collocantes. Haec enim sola supra firmam petram aedificata (reliquis a recta scripturae intelligentia quandoquidem deviantibus) immobilis semper in veritate permansit.' This justification sounds rather traditional. But even outside Roman Catholic circles humanists continued to regard a Latin form of the Bible as the biblical text par excellence. As an example we may cite Theodore Beza, who between $5_{5} 65$ and 1598 four times published a monumental edition of the New Testament in folio. Just as in Erasmus' edition, it contained the Greek text with a new Latin translation by Beza himself, printed alongside, and also the Vulgate and detailed Annotationes underneath. In I 598 Beza spoke of his first edition as: 'the troubles which I have taken on elucidating my Latin translation': 'meos istos illustrandae N. Testamenti Latinae translationi 
impensos labores' ${ }^{61}$ Beza had published a separate edition of his Latin translation as early as i 556 Obviously, he regarded his Greek-Latin edition of 1565 and its revisions as an 'illustration' of his Latin translation, the function of the Greek was to elucidate, to throw light upon, the Latin translation, not the other way round Clearly, the New Testament was still for Beza in princıple a Latın text $H_{1}$ approach, at least in this passage, is still that of Erasmus

My claim can be summed up in one sentence In judging the Greek text in Erasmus' editions of the New Testament, one should realize from the start that it was not intended as a textual edition in its own right, but served to give the reader of the Latin version, which was the main point, the opportunity to find out whether the translation was supported by the Greek In one of the forewords ${ }^{62}$ to the Novum Instrumentum Erasmus warned 'Let no one, like an unreasonable guest, demand a dinner instead of a light luncheon We state clearly what we have undertaken Let no one desire of us what is beyond this purpose '63

Henk Jan de Jonge

61 Second dedication to Elizabeth I of England, in Beza's fourth folio edition of the New Testament of 1598 , cited from the Cambridge reprint of 1642 , fol $3^{\text {ro }}$ Mr 'T van Lopık of Leiden brought this passage to my attention

${ }^{02}$ Foreword to the Annotationes (=Ep 373, ll 6-8) 'ne quis ut improbus conviva pro merenda coenam efflagitet, et requirat a nobis quod ab argumentı susceptı professione sit alienum ' To prevent new misunderstandings I point out that in his last years Erasmus was to deny that he had ever contemplated makıng a new Latın translation of the New Testament before 1514 (see, e g, Ep 2758, 11 I2-14 and $2807,1124-42$, both of 1533 , and notes) P S Allen already observed in his introduction to $E p \quad 384$ that this was a distortion of the facts Deeply dismayed and disturbed by the development of the Reformation, Erasmus tried to avold the impression that he had ever wished to supersede the Vulgate with his new translation A foreshadowing of the same subterfuge had already been found in $E p \quad 421$, ll $46-7$, of 1516

${ }^{63}$ For recent reactions to the thesis advocated in the present article, an earlier version of which appeared in Dutch in Lampas 15 ( I982), pp $23 \mathrm{I}-46$, see Jerry H Bentley, Humanists and Holy Writ (Princeton, 1983), 1v, 'Desiderius Lrasmus Christian Humanıst', pp I I2-93, see p I I4, and Heinz Holeczek's rcilcu in Wolfenbutteler Renaissance Mittezlungen, v11 2 (1983), pp 64-8 I w1sh to thank Dr J C Grayson of Liverpool for his translation of this article from Dutch 